WSRC-TR-92-110

\title{
TWF PROCESS CELL THROUGHPUT STUDY
}

WSRC-TR--92-110-Pt.1

by D. L. Fisher

Westinghouse Savannah River Company

Savannah River Site

Aiken, South Carolina 29808

Other Authors:
DE93 006874

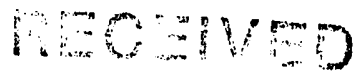

FEB - 51993

OSTI

This paper was prepared in connection with work done inder Contract No. DE-AC09-89SR18035 with the U. S. Department of Energy. By acceptance of this paper, the publisher and/or recipient acknowledges the U. S. Government's right to retain a nonexclusive, royalty-free license in and to any copyright covering this paper, along with the right to reproduce and to authorize others to reproduce all or part of the copyrighted paper.

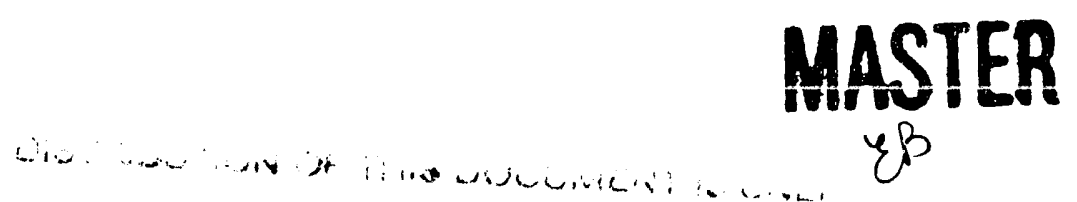




\section{DISCLAIMER}

This report was prepared as an account of work sponsored by an agency of the United States Government. Neither the United States Government nor any agency thereof, nor any of their employees, makes any warranty, express or implied, or assumes any legal liability or responsibility for the accuracy, completeness, or usefulness of any information, apparatus, product, or process disclosed, or represents that its use would not infringe privately owned rights. Reference herein to any specific commercial product, process, or service by trade name, trademark, manufacturer, or otherwise does not necessarily constitute or imply its endorsement, recommendation, or favoring by the United States Government or any agency thereof. The views and opinions of authors expressed herein do not necessarily state or reflect those of the United States Government or any agency thereof.

This report has been reproduced directly from the best available copy.

Available to DOE and DOE contractors from the Office of Scientific and Technical Information, P. O. Box 62, Oak Ridge, TN 37831; prices available from (615) $576-8401$.

Available to the public from the National Technical Information Service, U. S. Department of Commerce, 5285 Port Royal Rd., Springfield, VA 22161. 
KEYWORDS: Simulation, TRU Waste, Computer, Manipulator , Compactor.

WSRC-TR-92-110

RETENTION: Lifetime

February 28, 1992

TO:

M. G. Looper, 676-1T

FROM:

D. L. Fisher, 676-1T 4

\section{TWF PROCESS CEIL, THROUGHPUTSTUDY(U)}

\section{SUMMARY}

Dynamic computer simulation was used successfully to analyze a waste processing facility design and assess its performance. This strategic tool is now available to help our customers test waste processing designs/strategies, predict performance, and plan developmental work.

Waste Handling and Mechanical Processing (WH\&MP) used a dynamic computer simulation program to study a recommended design of the Transuranic Waste Facility (TWF) Waste Process Cell (WPC) (ref. 1). Transuranic Waste Test Facility (TWTF) campaign reports allowed portions of the computer output to be compared with waste processing data (ref.'s $2,3,4$ ).

The computer program simulated WPC operation for 6 months, recording equipment statistics, waiting times, material flow, contamination level, and outputs. With this information, underutilized equipment was identified and a need for buffers/queues was revealed. A combination of compactors and shredder reduced waste volume $19 \%$, and assay equipment locations were quantified. The throughput rate showed that a year's quota of waste can be processed in less than 8 months.

WH\&MP is extending its simulation capability with dynamic graphic displays. These show trends as they develop and allow continuous observation of waste processing.

\section{BACKGROUND}

The TWF will prepare transuranic (TRU) waste for permanent disposal at the Waste Isolation Pilot Plant (WIPP). WH\&MP's early participation in the TWF project included the installation and testing of a WPC mockup (using the conceptual design). Operating experience indicated significant improvements could be made in the WPC scheme, so we conducted a process cell equipment study with Equipment Engineering to identify better equipment and methods (ref. 4). The results of that study were used to construct the WPC computer simulation model. 


\section{INTRODUCTION}

The TWF WPC throughput study tests the usefulness of dynamic computer simulation in evaluating waste processing strategies and system performance. Unpacking, transport, drying, sorting, compacting, fixing/solidifying, cutting, shredding, assay, and repackaging are modeled. The simulation yields information on how well the processing scheme functions, how much the equipment is used, and areas and methods that need attention. The study was conducted to identify tools to support our Waste Management mission, and give reliable, documented bases for future processing and design decisions.

\section{DISCUSSION}

\section{Software}

The model was built and run on EXTEND (1.1n) manufacturing performance modeling software (Imagine That, Inc.) for the Apple Macintosh. It is compatible with Apple system 7.0 (i.e., virtual memory can be employed) and requires eight hours of computer time per month of simulated operation at 16 $\mathrm{MHz}$ (CPU clock speed).

The model uses three EXTEND function libraries: generic (continuous), discrete event, and manufacturing. The TWF library, created for this model, contains one EXTEND icon altered to visually identify the master slave manipulators and tele-robot.

\section{The Simulation Process}

The simulation process begins with a well defined problem and a problemsolving objective. Then a progression of steps is identified to solve the problem, these become the logic for the model. Each step must be identified with a realworld function (machine, queue, etc.) so that processing times and other variables can be assigned. Next, functions are matched with their corresponding logic, forming the model network.

Process variables (times, etc.) are assigned to each function and the simulation is run to verify the model functions as intended. Finally, experimental conditions are applied (input rate, breakdowns, etc.) and the simulation is run to record processing information. Results can be verified by statistical analysis (duplicate runs), or comparison to similar processes or mock-ups. For simple networks manual verification is possible, but tedious.

\section{Model Development}

We chose the TWF WPC Title I design as our problem because a Systems Engineering report indicates insufficient throughput capability (ref. 5). We defined our simulation objective as a process evaluation (throughput study) of the alternative plan offered in the TWF Equipment Study. It includes a floor 
(figure 1) and material flow pattern (figure 2). It also matches each waste processing function with a piece of equipment. The model network was constructed to simulate only the important processing functions (6).

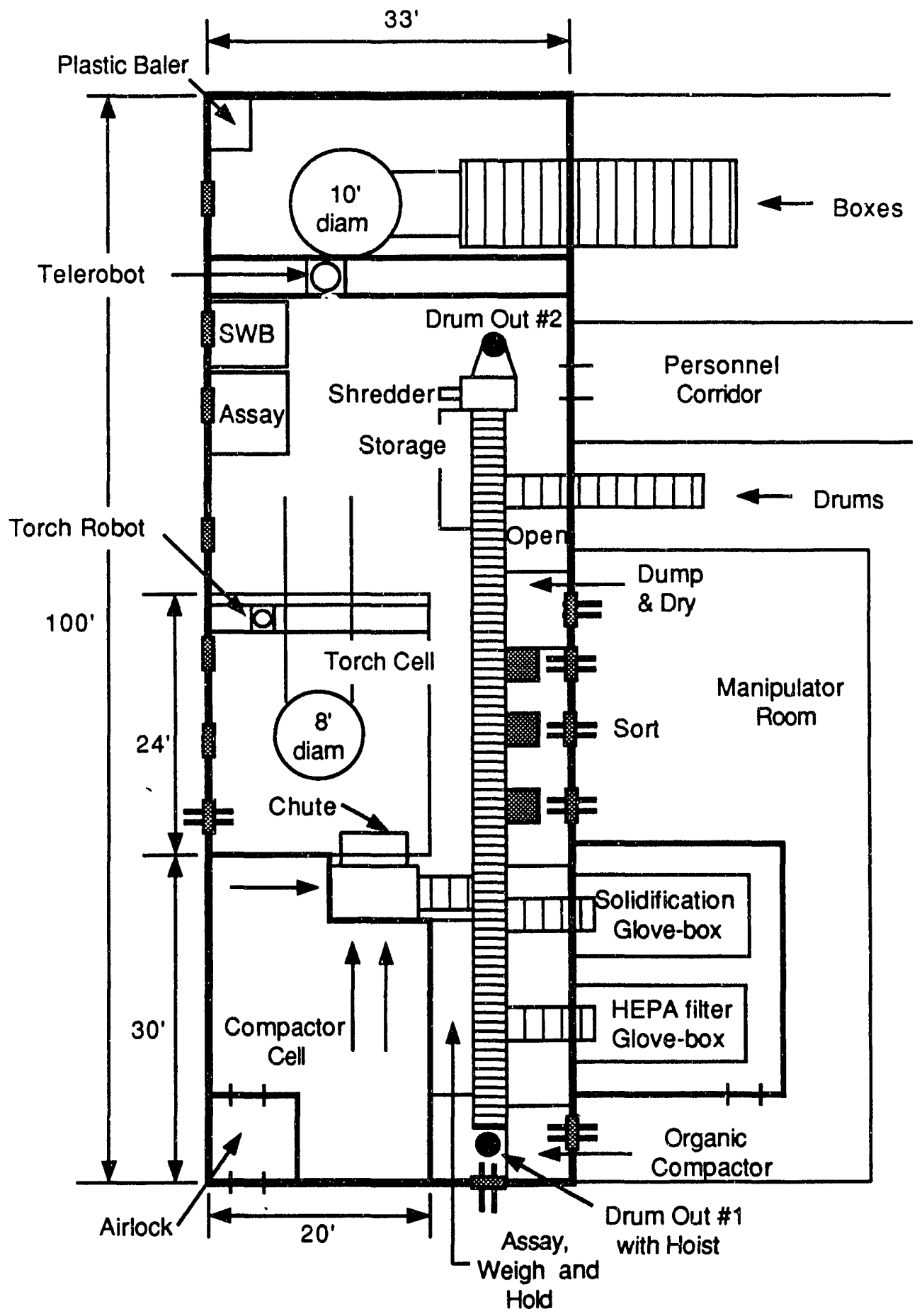

Figure 1. WPC Equipment and Layout 


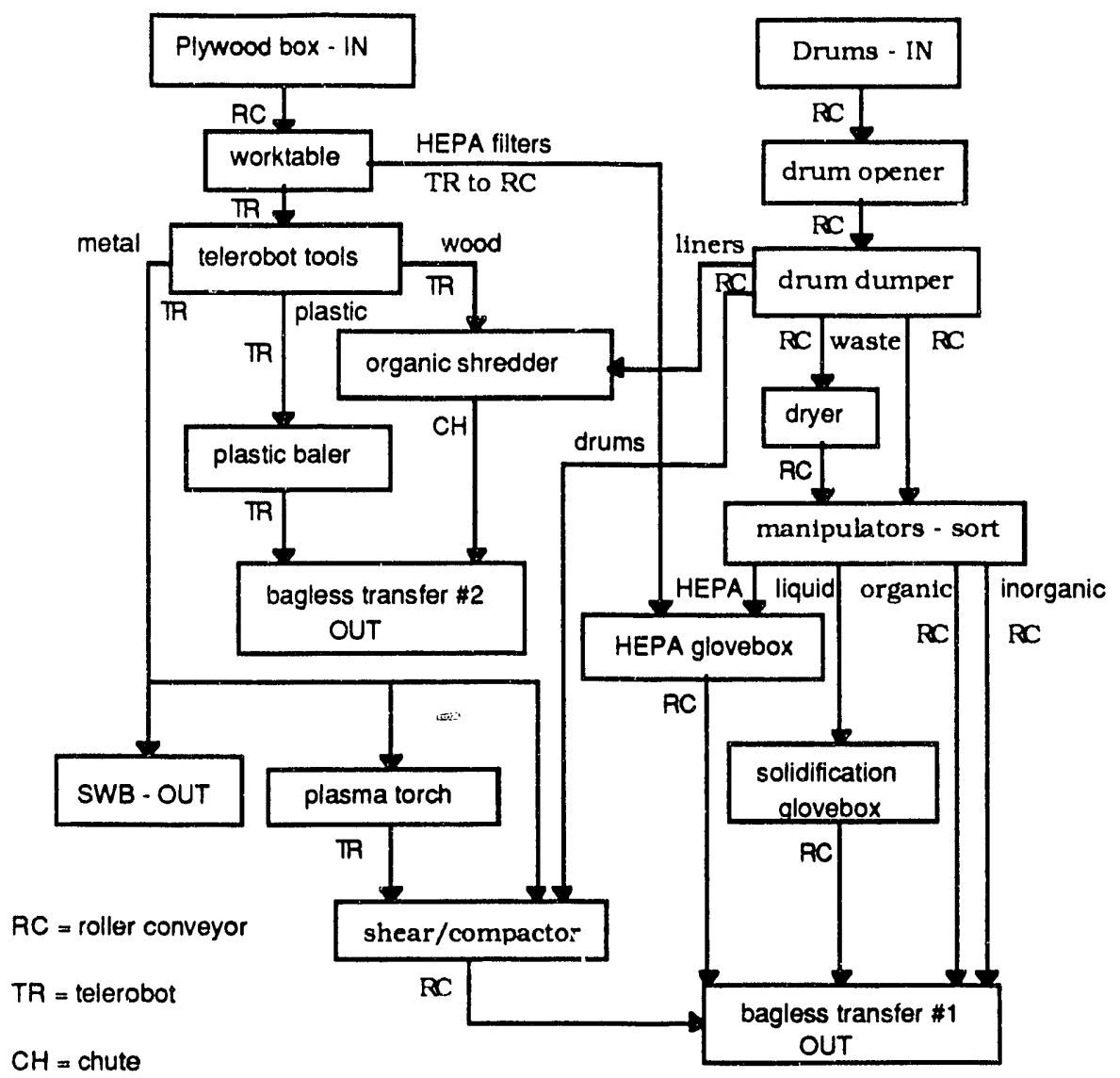

Figure 2. TWF Waste Process Cell Flow

The purpose of the TWF is to process temporarily stored TRU waste for disposal. Most TRU waste is in drums and large plywood boxes. Processing means opening containers, removing contents, sorting, drying, solidifying liquids, applying fixative to filters, cutting, shredding, and compacting so that processed waste can be repackaged in 55 gallon drums (see figure 2). The most important difference between the Title I and proposed designs is the restriction of the telerobot to box processing operations. The dexterity of a robot is unnecessary to process drums, which have standard shapes and sizes. Roller conveyors and a drum opener/dumper are used to free the telerobot for tasks more suited to its specialized capabilities.

The model network was assembled using the floor plan and flow diagram of the TWF Equipment Study. The drum processing network was completed first. A drum enters the cell every 90 minutes and travels on a roller conveyor to the opener and then to the dumping device. Empty drums and lids are compacted and polyethylene liners are shredded. Eight shredded liners fill 1 drum at bagless transfer machine \#2 (organic materials only). Three percent of the waste dumped out of drums is considered to be wet and goes to the dryer. The rest goes to master-slave manipulators for sorting. 
Manipulators group the waste into 4 categories: organic, inorganic, HEPA filters, and liquid (in containers). After sorting, HEPA filters go to a glove-box for fixative application, and liquids in containers go to a glove-box for solidification. The output of these two steps joins waste from the manipulators and the shear/compactor on the roller conveyor. Packages are assayed individually before accumulating at two buffer areas near bagless transfer \#1, one each for organic and inorganic material. Packaging these wastes separately allows more waste to be shipped in each drum due to improved assay accuracy.

Box processing was developed next, eventually interfacing with drum line equipment. Large boxes of TRU waste are input each 1.5 days. Ninety percent of the boxes contain inorganic waste and have a mean volume of $125 \mathrm{ft}^{3}$. Ten percent contain HEPA filters (12/box). Boxes travel on a roller conveyor to the worktable and are opened by a gantry mounted telerobot (with cutting tools). Ten percent of the original volume is removed as wood waste and taken to the shredder by the telerobot (exiting the cell through bagless transfer \#2). The plastic wrap covering the waste is removed by the telerobot and taken to a baler which fills one drum ( $55 \mathrm{gal}$ ) for every 3 waste boxes processed. Bales are sent to bagless transfer \#2 where they are assayed and exit the cell. The remaining ninety percent of the volume is divided into items that need to be cut into smaller pieces $(67 \%)$, and items that do not (33\%). Waste in the box processing area is transported by overhead crane or telerobot to the cutting area (plasma arc torch) and/or to the shear/compactor. The plasma arc torch output goes to the shear compactor. One of every 15 items is considered unsuitable for compaction and is placed in a standard waste box (SWB). Shear/compactor output travels by roller conveyor for assay and loading into a drum at bagless transfer \#1.

During model development, short term simulations (1 to 10 days) were conducted at high waste input rates ( $8 \mathrm{x}$ minimum rate) to rapidly determine if the model performed as designed. These runs flagged the HEPA and liquid processing glove-boxes as bottlenecks due to long drying times. Drying racks were added allowing a batch of items io be processed in a short time and eliminating waste back-up at these stations. Buffers were placed strategically in the model to allow more efficient batch processing.

\section{Model Parameters}

The TWF's minimum waste processing rate is based on the 20 year disposal period of the Waste Isolation Pilot Plant (WIPP). $25,500 \mathrm{ft}^{3}$ of waste must enter the TWF each year (ref. 7) to process the entire inventory of TRU waste in 20 years. Available processing time will be reduced by maintenance and repairs, radionuclide inventory control, and decontamination. Facility stand-downs or regulatory changes may also reduce the processing time. It is obvious that input rates must be high enough to compensate for delays. In order to do this, the waste input rate of the model was arbitrarily accelerated two and one half (2.5) times, to $178 \mathrm{ft}^{3}$ per day.

Each waste item entering the cell is assigned a waste type, volume, and gram 
amount of Plutonium $(\mathrm{Pu})$. These are not expected $\mathrm{Pu}$ amounts, but represent some quantity of radioactive material on the waste. The values are assigned to provide a way to track this characteristic and monitor build-up in the cell. Quantities average $1 \mathrm{~g}$ for items found in drums ( 3 to 5 per drum) and $4 \mathrm{~g}$ for waste from boxes (1. to 12 per box). Waste is assayed before repacking. Waste types entering the cell, their containers, and frequency of appearance are:

\begin{tabular}{lcc}
\multicolumn{1}{c}{ Waste } & Drum & Box \\
\hline \hline organic & $67 \%$ & $9 \%$ (wood \& plastic wrap) \\
inorganic & 23 & 81 \\
HEPA \& other filters & 7 & 10 \\
liquid (in containers) & 3 & 0
\end{tabular}

The TWF concept incorporates a large, open cell for WPC operations. This allows use of the overhead crane and the telerobot for equipment $r$ pair and operational tasks. Some maintenance tasks will require personnel entry into the cell, so reducing the transferable contamination level in the cell will be required first. Since the cell is large $\left(33^{\prime} \times 100^{\prime} \times 40^{\prime}\right)$, this will require a reasonable period of time and must be included in the model.

Table 1 lists the WPC equipment parameters. Failure rates used in the model were gathered from test results, experienced SRS personnel, vendor information, and engineering judgment (for equipment items not yet developed). The onset of equipment failures was artificially accelerated to observe the effects on processing without simulating many years of cell operation.

\begin{tabular}{|c|c|c|c|c|c|}
\hline $\begin{array}{l}\text { Equipment } \\
\text { Item }\end{array}$ & $\begin{array}{c}\text { Process } 1 \\
\text { Time } \\
\end{array}$ & $\begin{array}{l}\text { Maint. or } 1 \mathrm{st} \\
\text { Failure@ } \mathrm{t}=\end{array}$ & $\begin{array}{l}\text { Maint/Fail } \\
\text { Frequency }\end{array}$ & $\begin{array}{l}\text { Maint. } \\
\text { Quration }\end{array}$ & $\begin{array}{l}\text { Volume } \\
\text { Reduction }\end{array}$ \\
\hline & on us & & & & \\
\hline Conveyors & $20 \mathrm{ft} / \mathrm{min}$. & 0 & $6 \mathrm{mo}$. & $3 \mathrm{hr}$. & 0 \\
\hline Drum opener & $18 \mathrm{~min}$. & 5.5 days & $4 \mathrm{mo}$. & 1 day & 0 \\
\hline Drum dumper & $15 \mathrm{~min}$. & 1 wk. & 6 mo. & 2 days & 0 \\
\hline Waste dryer & $1 \mathrm{hr}$. & 3.5 days & $6 \mathrm{mo}$. & $1 \mathrm{hr}$. & 0 \\
\hline ulators & 3 items $/ d$ r & Irum, process & lime/item: & & \\
\hline$\# 1$ & $15 \mathrm{~min}$. & $2 \mathrm{hr}$. & $2 \mathrm{yr}$. & $4 \mathrm{hr}$. & 0 \\
\hline \# 2 & $15 \mathrm{~min}$. & 1.5 wk. & $2 \mathrm{yr}$. & $4 \mathrm{hr}$. & 0 \\
\hline$\# 3$ & $15 \mathrm{~min}$. & $3.3 \mathrm{mo}$. & $2 \mathrm{yr}$. & $4 \mathrm{hr}$. & 0 \\
\hline HEPA fix & $5 \mathrm{hr}$. & 2 wk. & 2 wk. & $4 \mathrm{hr}$. & 0 \\
\hline Solidify liq. & $5 \mathrm{hr}$. & 1 wk. & 1 wk. & $4 \mathrm{hr}$. & 0 \\
\hline $\begin{array}{l}\text { Shredder, } \\
\text { organic }\end{array}$ & $10 \mathrm{~min}$. & $1.2 \mathrm{wk}$. & $1 \mathrm{mo}$. & $16 \mathrm{hr}$. & $\begin{array}{c}8: 1 \text { (liners) } \\
0 \text { (wood) }\end{array}$ \\
\hline $\begin{array}{l}\text { Bagless } \\
\text { transfer \#1 }\end{array}$ & $7 \mathrm{~min}$. & 1.5 wk. & $2 \mathrm{mo}$. & 1 day & 0 \\
\hline $\begin{array}{l}\text { Bagless } \\
\text { transfer \#2 }\end{array}$ & $7 \mathrm{~min}$. & 1.75 wk. & $3 \mathrm{mo}$. & 1 day & 0 \\
\hline Worktable & $40 \mathrm{~min}$. & none & none & none & 0 \\
\hline
\end{tabular}

Table 1. Equipment Parameters (continued on p.7) 


\begin{tabular}{|c|c|c|c|c|c|}
\hline $\begin{array}{c}\text { Equipment } \\
\text { Item }\end{array}$ & $\begin{array}{c}\text { Process } \\
\text { Time } \\
\end{array}$ & $\begin{array}{l}\text { Maint. or 1st } \\
\text { Failure@t= }\end{array}$ & $\begin{array}{l}\text { Maint/Fail } \\
\text { Frequency } \\
\end{array}$ & $\begin{array}{l}\text { Maint. } \\
\text { Duration } \\
\end{array}$ & $\begin{array}{l}\text { Volume } \\
\text { Reduction } \\
\end{array}$ \\
\hline Telerobot & $20 \mathrm{ft} / \mathrm{min}$ & 0 & 3.3 wk. & $16 \mathrm{hr}$. & 0 \\
\hline Plasma torch & $8.3 \mathrm{hr}$. & 0 & 2 days & $30 \mathrm{~min}$ & 10 to 1 \\
\hline $\begin{array}{l}\text { Shear/com- } \\
\text { pactor }\end{array}$ & $2 \mathrm{~min}$. & 2.86 wk. & $6 \mathrm{mo}$. & 1 day & 5 to 1 \\
\hline Plastic baler & $2 \mathrm{~min}$ & 0 & $8 \mathrm{mo}$. & 1 day & 3 to 1 \\
\hline SWB & $2 \mathrm{hr}$. & none & none & none & 0 \\
\hline Gantry crane & factored & - repair times & negligible & effect & 0 \\
\hline
\end{tabular}

Table 1. Equipment Parameters (continued from p. 6)

\section{Simulated Waste Processing}

The simulation uses a waste input rate of $178 \mathrm{ft} 3 /$ day which was chosen arbitrarily within the imposed limits (minimum throughput requirement and maximum waste retrieval rate). This rate is considered constant except when certain cell equipment problems halt input, and resumes when the condition is corrected. It is important to remember the waste input rate is variable and affects the throughput.

Six months of continuous WPC operation were simulated, during which 31,700 $\mathrm{ft}^{3}$ of waste entered the cell and 25,600 $\mathrm{ft}^{3}$ left. Since negligible quantities of waste remeined in the cell, this indicates a volume reduction of $19 \%$ during processing. Mlost of the waste (98\% of total volume) left the cell in drums, the remainder left in Standard Waste Boxes. Figures 3 and 4 show the first month's output from the two bagless transfer stations, clearly showing the effects of equipment failures (refer to table 1 ).

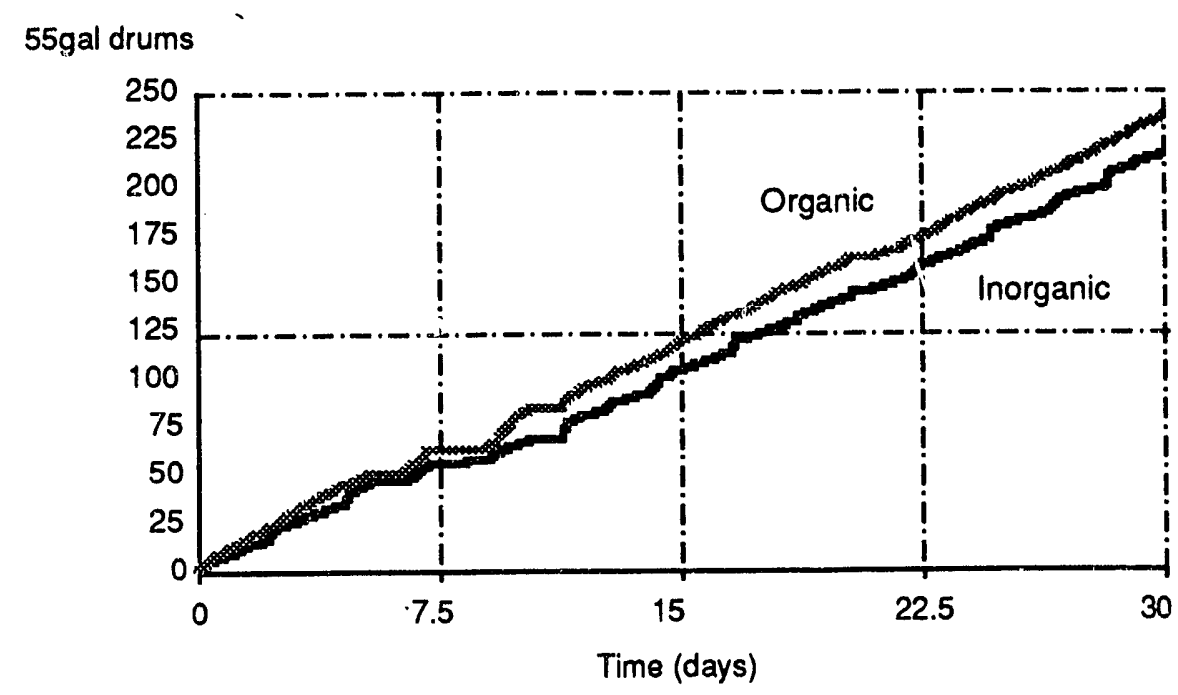

Figure 3. Bagless Transfer \#1 Output (Organic \& Inorganic) 


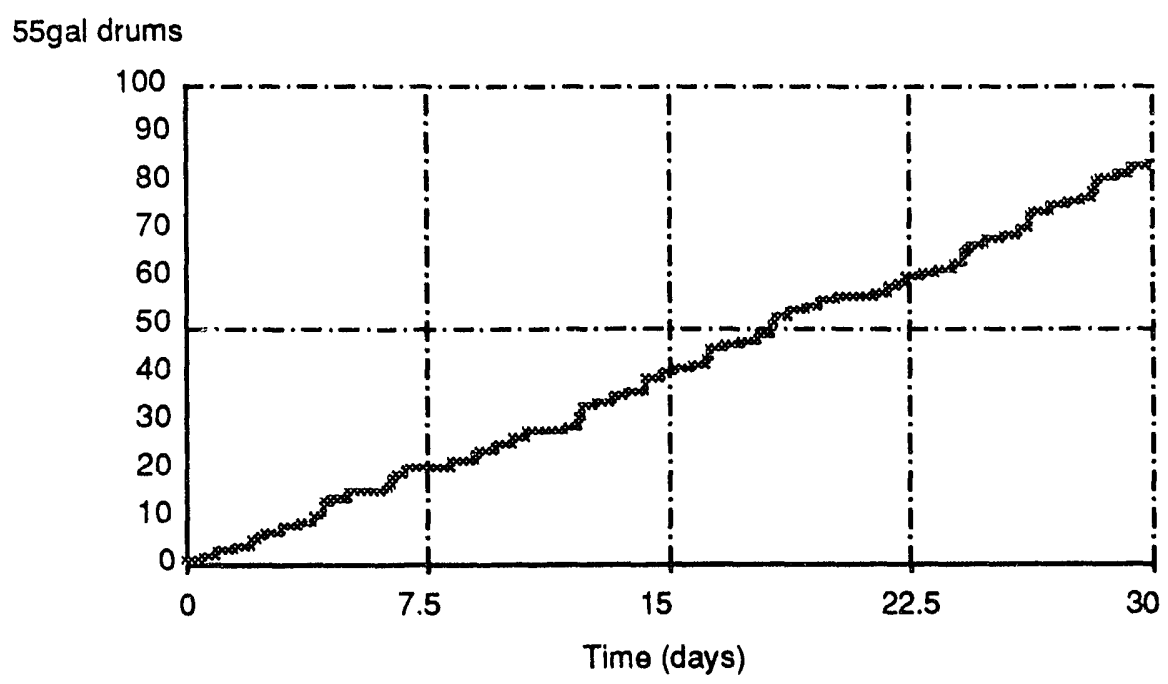

Figure 4. Bagless Transier \#2 Output (Organic Waste)

TWTK campaign reports show small increases in waste volume (ref. 2).

How or the conceptual design used at the TWTF did not incorporate a shear/ compantor or plastic baler, so the volume reduction predicted by the model is reasonable when compared with processing experience.

Figure 5 shows the simulated WPC Pu inventory for the first month. Spikes are evident when a box full of HEPA filters (12/box) enter the cell and when various equipment is off-line (see table 1). No error was included and, although the processing equipment will be contaminated, this was not simulated.

Contamination levels in the cell can be modeled to predict decontamination schedules if desired.

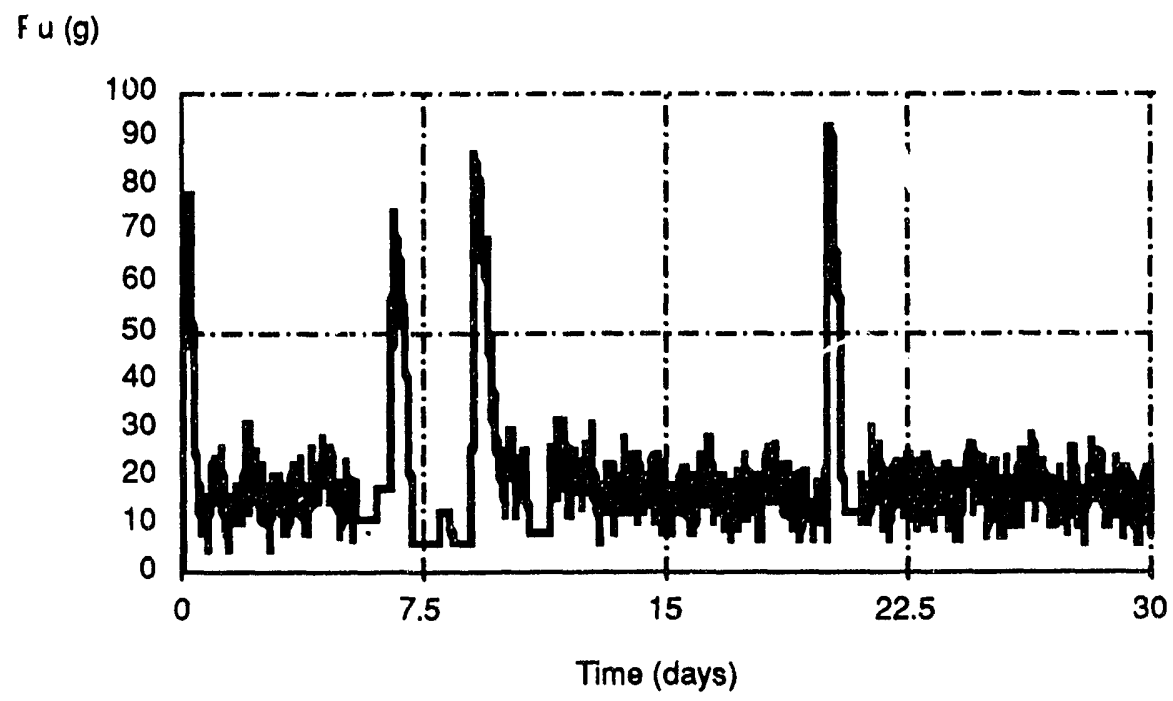

Figure 5. Cell Pu Inventory 


\section{CONCLUSION}

Computer simulation supplies performance information that allows us to confidently modify a recommended processing scheme, and more. It is a tool that can provide our customers with a documented basis to make engineering decisions about their real-world processes

- before building them - to make design or feasibility choices

- without disturbing them - if experiments present safety problems or are costly to perform

- without destroying them - to find limits of endurance (ref. 6).

Simulation helps focus attention on the critical problem(s) and enables quick response to many of our customer's feasibility and performance questions.

This investigation supports the following clarifications or changes to the TWF Equipment Study recommendation:

- A single master-slave manipulator pair (2 arms) is required for sorting waste removed from drums (reduced from 3 pairs). A single manipulator pair will be in operation $50 \%$ of the time.

- Buffers or temporary holding areas are needed (not previously specified).

1 upstream of the waste dryer station

2 upstream of bagless transfer machine \#1 (to keep organic and inorganic waste separate)

- HEPA glove-box may require holding area

- Drying areas are needed.

4 to 8 positions at the HEPA glove-box

2 to 4 positions at the liquid processing glove-box

Batches of waste are processed faster when drying areas are available (helps keep cell radionuclide inventory lower).

- Assay stations are needed at each cell output to facilitate maximum waste loading in the containers (drums/SWBs) sent for disposal. (for the current assay plan)

3 upstream of bagless transfer $\$ 1$ (each operating at $55 \%$ capacity)

1 at bagless transfer $\# 2$, and

1 upstream of the standard waste box.

Three (3) to five (5) waste items fill a drum (at bagless transfer \#1) and each is assayed for 40 minutes. Bagless transfer \#2 fills drums 
with waste from the organic shredder and assays them when full. Individual items are assayed before being placed in the Standard Waste Box.

The WPC throughput is $41,000 \mathrm{ft}^{3}$ per year (with an input of $178 \mathrm{ft}^{3}$ per day), which is 1.6 times the required annual volume. The input rate is important because it affects the throughput rate and defines the minimum waste retrieval rate from interim storage. The excess throughput capability may be required to make up for time used during decontamination and other operating delays. Equipment repair and maintenance were part of the simulation and the minimum equipment utility (defined in the FPR) was applied to the throughput result.

\section{QUALITY ASSURAN}

The software used to model the WPC is the current version of Extend (1.1n). Imagine That Inc. informs Extend owners of changes/corrections, and has not reported any problems. A copy of the model and simulation data are included as an attachment to the file copy this report.

The throughput study focuses on the ability of recommended equiprnent to perform a series of tasks at a specified rate. The processing time required by each piece of equipment is therefore key to this study. Repair and maintenance frequencies and times are also important. Times were established by internal technical reports (see references) for equipment which is, or has been used at the Savannah River Site. Times unavailable in reports were supplied by WSRC personnel having experience with the same or similar equipment. These sources are recorded in the model dialog supplied with the record copy of the report. Vendors were contacted for information on equipment that is commercially available but has not been used on site. In cases where equipment has not been developed or the information is not available, engineering judgment was used to establish process rates.

\section{REFERENCES}

1. E. M. Kriikku, TWF Equipment Evaluation Study (U), USDOE Report WSRC-TR-90.288, Savannah River Site, Aiken, SC 29808 (1990).

2. B. S. Hoekstra, TRU Waste Test Facility Campaign (U), USDOE Report DPST-88-615, Savannah River Site, Aiken, SC 29808 (1988).

3. R. S. Simpson, Transuranic Waste Shredding Tests (U), USDOE Report DPST-88-1041, Savannah River Site, Aiken, SC 29808 (1988).

4. E. M. Kriikku, TRU Waste Test Facility Campaigns 2 and 3 (U) , USDOE Report WSRC-RP-89-629, Savannah River Site, Aiken, SC 29808 (1989). 
5. H. L. Bhula, W. E. Perry, Transuranic Waste Facility Throughput Study (U), USDOE Report WSRC-RP-91-497, Savannah River Site, Aiken, SC 29808 (1991).

6. A. Alan B. Pritsker, Introduction to Simulation and SLAM II, Halsted Press and Systems Publishing Corporation, 1986.

7. Functional Perform ance Requirements; Transuranic (TRU) Waste Faciiity (U) , S-2991, USDOE Memo OPS-WMP-89-3667, Savannah River Site, Aiken, SC, 29808 (1989).

Distribution:

W. L. Tamosaitis, 773-A

S. J. Mentrup, 707-H

J. E. Stumbuagh, 707-H

L. Williams, 676-T

E. M. Kriikku. 676-1T

IWT file

SRTC file (4) 

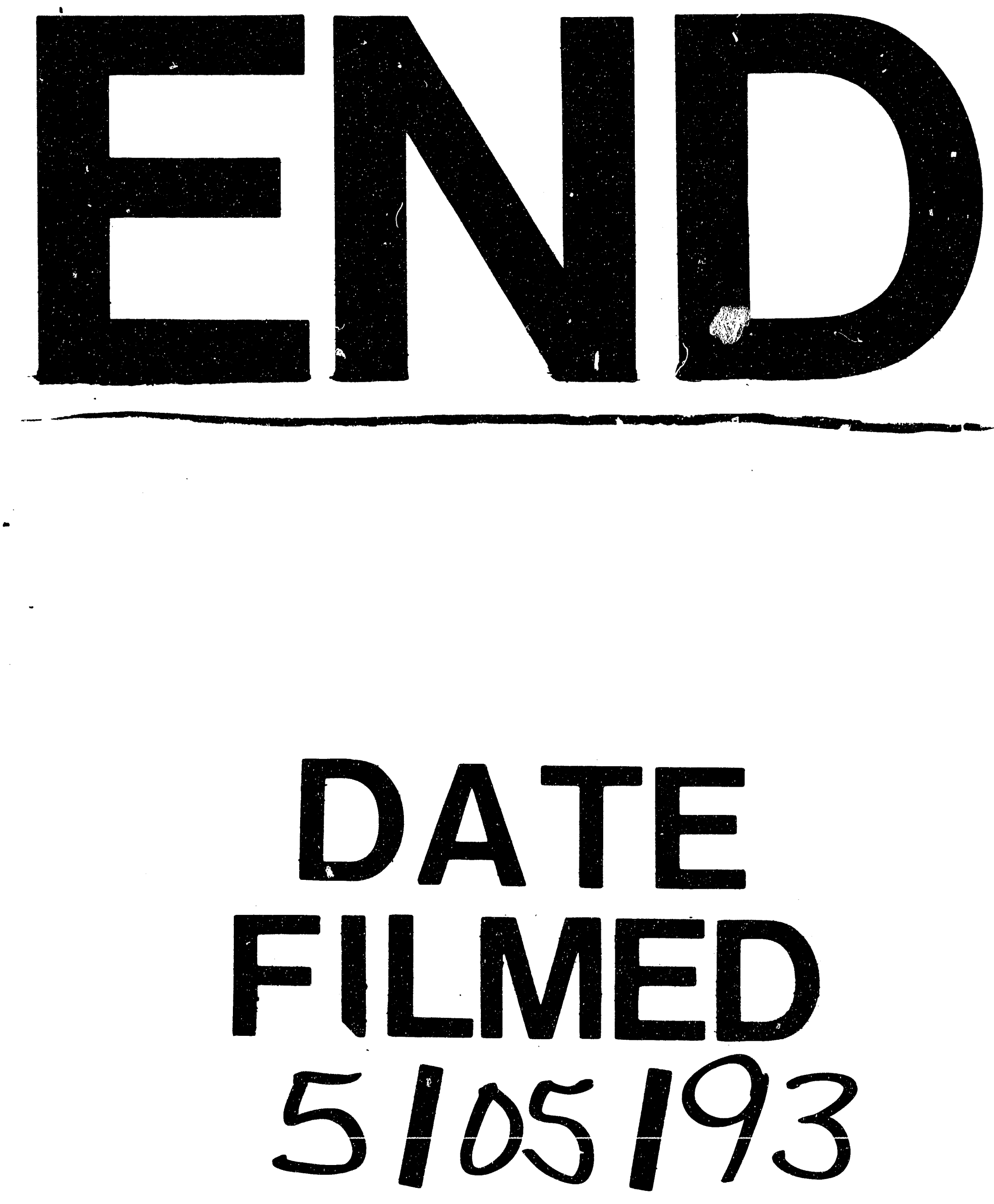
